\title{
De-historification (1944-1948): Shamanic Magic and the Dialectic Movement between Mircea Eliade and Claude Lévi-Strauss
}

\author{
The Integration of Eliade and Lévi-Strauss: Sacred Poles and Songs \\ of Labor as Forms of De-historification
}

After Vittorio Macchioro recommended Eliade's Yoga: An Essay on the Origins of Indian Mysticism (1936) to his new son-in-law shortly after its publication, de Martino's legacy leaves no traces of the Romanian giant for a decade. ${ }^{1}$ Even though Eliade's lengthy article entitled "The Problem of Shamanism" (1946) is absent in de Martino's The World of Magic, ${ }^{2}$ it is around this same time that he recommenced to engage the work of his famous Romanian counterpart. Responding to the recently published Techniques of Yoga (1948), de Martino showed himself visibly impressed with it, particularly with its sensibility for the religious conception of time and history. ${ }^{3}$ His review, published in Pettazzoni's prestigious journal Studies and Materials of History of Religions, ${ }^{4}$ was generous with praise.

This work by Mircea Eliade responds very well to the general requirement for the Western culture to broaden its own humanism and to renew its own problems by means of the comprehension of forms of spirituality that are ideally distant from ours. According to the author, the paradox of Yoga (reintegration in all the forms of the indistinct, in the primordial unity) can be understood in light of the archaic aspiration to abolish history, to restore the auroral state, periodically and ritually renewing the "archetype time," the time of the origins. [...] Without a doubt, this interpretation of yoga and of its techniques is extremely suggestive and incisive. ${ }^{5}$

1 Mircea Eliade, Yoga: Essai sur les origines de la mystique indienne (Paris: Geuthner, 1936).

2 Mircea Eliade, "Le problème du chamanisme," Revue de l'histoire des religions 131, no. 1 (1946): $5^{-52 .}$

3 Mircea Eliade, Techniques du yoga (Paris: Gallimard, 1948).

4 Ernesto De Martino, "Recensione a M. Eliade, 'Techniques du yoga," Studi e materiali di storia delle religioni 21 (1948): 130-32.

5 De Martino, 13 . 
Even more, he also added it, fresh off the press, to the books to be published in the Purple Series. ${ }^{6}$ Charging his wife-from whom he just recently separated - with the task of translating the book from French into Italian, de Martino himself redacted the preface to the translation. De Martino's various efforts to promote his colleague's work were not only instrumental in the reception of Eliade amongst a general Italian public, ${ }^{7}$ but also points to a shared fascination with the theory of religion as a "flight from history." This, indeed, was the most significant novelty of Eliade's new book and would turn into a cornerstone for the rest of Eliade's work and de Martino's analysis thereof. ${ }^{8}$ Unlike his all too often ignored interests in parapsychology, ${ }^{9}$ scholarship has rightly noted to what extent de Martino's most significant theoretical contribution to his field of study is indebted to Mircea Eliade's writings on time and history. ${ }^{10}$

$6 \quad$ Mircea Eliade, Tecniche dello yoga (Torino: Einaudi, 1952).

7 Pietro Angelini, "Eliade, de Martino e il problema dei poteri magici," in Mircea Eliade: le forme della tradizione e del sacro, ed. Giovanni Casadio and Pietro Mander (Roma: Edizioni Mediterranee, 2012), 11-38.

8 Raffaele Pettazzoni, "The Truth of Myth," in Essays on the History of Religions (Leiden: Brill, 1954), 11-23; Sharpe, Comparative Religion, 215; Douglas Allen, "Ist Eliade antihistorisch?," in Die Mitte der Welt: Aufsätze zu Mircea Eliade, ed. Hans Peter Duerr (Frankfurt am Main: Suhrkamp, 1984), 106-27; Strenski, Four Theories of Myth in Twentieth-Century History; Jonathan Z. Smith, Map Is Not Territory: Studies in the History of Religions (Chicago: University of Chicago Press, 1993); Phillippe Borgeaud, "Mythe et Histoire Chez Mircea Eliade. Réflexions d'un Écolier En Histoire Des Religions," Institut National Genevois, Annales 1993, 1994, 33-48; Natale Spineto, "Introduction," in L'histoire des religions a-t-elle un sens? Correspondance 1926-1959 (Paris: Le Cerf, 1994); Christian Wachtmann, Der Religionsbegriff bei Mircea Eliade (Frankfurt am Main: Peter Lang, 1996); Natale Spineto, "Raffaele Pettazzoni e la verità del mito," Rivista di storia della storiografia moderna 17 (1997): 59-65; Philip Vanhaelemeersch, "Eliade, 'History' and 'Historicism,"' in The International Eliade, ed. Bryan S. Rennie (Albany: State University of New York Press, 2007), 155-61.

9 Geisshuesler, Flavio, "A Parapsychologist, an Anthropologist, and a Vitalist Walk into a Laboratory: Ernesto de Martino, Mircea Eliade, and a Forgotten Chapter in the Disciplinary History of Religious Studies."

10 Ugo Bianchi, History of Religions (Leiden: Brill, 1975), 197-98; Giuseppe Giarrizzo, "Note su Ernesto de Martino," Archivio italiano di storia della cultura VIII (1995): 162; Angelini, "Il rapporto tra Ernesto de Martino e Mircea Eliade," 216-19; Angelini, "Eliade, de Martino e il problema dei poteri magici"; Giovanni Casadio, Lo sciamanesimo. Prima e dopo Mircea Eliade (Roma: Il Calamo, 2014); Cecilia Gatto Trocchi, "L'occultismo in Occidente secondo Eliade: fascinazioni e inquinamenti," in Confronto con Mircea Eliade: archetipi mitici e identità storica, ed. Luciano Arcella, Paola Pisi, and Roberto Scagno (Milano: Jaca Book, 1998), 319-36; Sergio Botta, "La via storicista allo sciamanesimo: prospettive archeologiche e storia delle religioni," in Sciamani e sciamanesimi, ed. Alessandro Saggioro and Leonardo Ambasciano (Roma: Carocci, 2010), 59-86; Christine Bergé, "Lectures de De Martino en France aujourd'hui," ETHN Ethnologie française XXXVII, no. 2 (2001): 537-47. 
Before exploring the interactions between de Martino and his Romanian colleague, however, it is important to note that the magnetic enthrallment with temporality and its role in religion was already a core characteristic of the young Ernesto. In notes written during the 1930s, for instance, we read:

Religion is the negation of development. Rituals and myths, in enormously distant lands and times, repeat apparently similar situations: There is something, at the root of religion, which does not want to become, which desperately attempts to solidify the spirit in nature. [...] Hence, the historian of religion is compelled to make history (fare la storia) of that which is, by its very nature, the aspiration to avoid history. Writing (fare) the history of a religion means to reproduce (rifare) the process by which this aspiration was defeated and consumed-like all human aspirations-by time. In this sense, religion is unwillingly history, [it is the] drama between reality (development) and abstract being (nature). ${ }^{11}$

This being said, the term "de-historification" rose to prominence only after de Martino actively engaged the work of Mircea Eliade in the years immediately following the war. ${ }^{12} \mathrm{Of}$ the dozens of examples throughout the rest of his life, ${ }^{13}$ the clearest expression of Eliade's religious conception of time as characterized by a "nostalgia for origins," is arguably to be found in his Myth of the Eternal Return: Cosmos and History (1949). ${ }^{14}$ In the book, which he considered to be his most important one, ${ }^{15}$ Eliade famously claimed that religion seeks to escape our historical reality choosing to 'live in an 'eternal present,' outside of time [...] by deliberately repeat[ing] such and such acts posited $a b$ origine by gods, heroes, or ancestors."16

11 Capocasale, "Gli appunti inediti giovanili di Ernesto de Martino per un 'Saggio sulla Religione civile," 19-20.

12 Ernesto De Martino, "Note di viaggio," Nuovi Argomenti 1, no. 2 (June 1953): 47-79.

13 See, for example, Mircea Eliade, Images et symboles: essais sur le symbolisme magicoreligieux (Paris: Gallimard, 1952); Mircea Eliade, "Kosmogonische Mythen und magische Handlungen," Paideuma VI (1956): 194-204; Mircea Eliade, Mythes, rêves et mystères (Paris: Gallimard, 1957); Mircea Eliade, "The Prestige of Cosmogonic Myth," Diogenes XXIII (1958): 1-13; Mircea Eliade, "The Quest for the 'Origins' of Religion," History of Religions 4, no. 1 (July 1, 1964): 154-69; Mircea Eliade, "Cosmogonic Myth and 'Sacred History," Religious Studies 2, no. 2 (1967): 171-83.

14 Mircea Eliade, Le Mythe de l'éternel Retour (Paris: Gallimard, 1949).

15 Mircea Eliade, The Myth of the Eternal Return: Cosmos and History, trans. Willard R. Trask (New York: Pantheon Books, 1954), ix.

16 Eliade, $5^{-6 .}$ 
De Martino believed that his colleague was correct in assuming that the flight from historical reality was an essential trait of religion. Even more, he agreed that that religion is a complex consisting of both ritual and myth, in which the ritual repetition of mythic accounts allows the practitioner to negate or obscure history, thus escaping historical reality through the metahistorical universe of myth. As the subtitle to the book's French edition-Archetypes and Repetition -implies, Eliade argued that ritual acts are used "to annul past time, to abolish history by a continuous return in illo tempore, by the repetition of the cosmogonic act."17 De Martino summarized this posture as follows:

According to Eliade, the historian of religion studies facts that, despite being inserted into the flux of becoming, manifest a behavior that to a great extent transcends the historical behavior of the human being. At the heart of the various religions always the same "archetypes" are at work, that is to say the same images and the same fundamental symbols, in which the human condition as such expresses itself beyond all ages and all civilizations. In this way, according to Eliade, the religious pretense to escape history and to resolve it in the ritual repetition of archetypes, has a certain sense of effective ontological value: the historian and the phenomenologist of religion get mixed up with the man engaged in religion in at least one aspect, inasmuch as they confirm the fundamental religious aspiration to escape from history. ${ }^{18}$

It was in 1952, shortly after Eliade himself published his most famous book on the theme as Shamanism: Archaic Techniques of Ecstasy (1951), ${ }^{19}$ that de Martino personally contacted the Romanian scholar. In his letter, he informed the Romanian scholar about his plans to publish an investigation on the myth and ritual practices surrounding the sacred pole of an Australian aborigine nomadic people made famous in Eliade's studies. That same year, the results of this investigation were published in the form of an article entitled "Territorial Anguish and Cultural Redemption in the Achilpa Myth of Origins" (1952). ${ }^{20}$

17 Eliade, 81.

18 Ernesto De Martino, "Prefazione," in Trattato di storia delle religioni, by Mircea Eliade (Torino: Einaudi, 1954), IX.

19 Mircea Eliade, Le chamanisme et les techniques archaïques de l'extase (Paris: Payot, 1951).

$20 \quad$ Ernesto De Martino, "Angoscia territoriale e riscatto culturale nel mito Achilpa delle origini. Contributo allo studio della mitologia degli Aranda," Studi e materiali di storia delle religioni 23 (1952 1951): 52-66. 
In this composition, which has been lauded as "one of the highest and most mature expressions of contemporary anthropology,"21 de Martino investigated the myths and practices of an Australian people; paying particular attention to its use of a ceremonial pole, known as "Kauwa-Auwa." The Italian scholar of religion demonstrated how the ritual object is used to relieve the nomadic people's anxiety associated with constantly having to move to new places. Explicitly acknowledging his debt to Eliade, he argued that the pole is central to certain "rituals," which are performed to "symbolically repeat the act of creation."22 For de Martino, Eliade's studies on "foundational events that took place in illo tempore" are "relevant" because they show how religion works with acts that "can be ceremonially reiterated." 23

In his subsequent writings, de Martino deepened his exploration of the crisis and the recovery of the "presence" as "de-historification." 24 Focusing on primitive societies and magical practices, he argued that they are cultural techniques of recovery that address critical moments of existence and act as protection to both individual and collective identities, ultimately leading to the strengthening of the presence by imbuing it with community values. De-historification works by temporarily concealing the destructive potential of personal and collective crises, be they natural disasters, economic oppression, or the loss of a family member. In so doing, it transposes these critical moments and their negative implications into a metahistorical realm where the incidents are actively mastered and brought under control. De-historification, therefore, does not only allow to frame the historical crisis in a mythic and optimistic horizon where it has already been resolved at the beginning of time, but it also aids the reintegration of the individuals and communities affected by the incident.

In another article, de Martino remarked again that what Eliade calls "the archaic ontology" consists in the "resolution of the historical becoming in the repetition of mythic archetypes, primordial events that took place once and for all in illo tempore."25 This repetition of myths in order to escape history, so de Martino observed, could be summed up with the expression "stepping

21 Marcello Massenzio, "Destorificazione istituzionale e destorificazione irrelativa in E. de Martino," Studi e materiali di storia delle religioni 51, no. 9 (1985): 199.

22 De Martino, "Angoscia territoriale e riscatto culturale nel mito Achilpa delle origini. Contributo allo studio della mitologia degli Aranda," 2012, 227.

23 De Martino, 227.

24 Ernesto De Martino, "Fenomenologia religiosa e storicismo assoluto," Studi e materiali di storia delle religioni 24-25 (1954 1953): 1-25. See also, the ample archival notes on this theme published by Marcello Massenzio. Ernesto De Martino, Storia e metastoria: ifondamenti di una teoria del sacro, ed. Marcello Massenzio (Lecce: Argo, 1995).

De Martino, "Mito, scienze religiose e civiltà moderna," 44. 
back" (passo indietro). He used this formulation to discuss his Romanian colleague's conception of magic and argued that "the scholar who has treated this 'step backwards' in the mythical-ritual nexus the longest and with the greatest abundance of data, is, without a doubt, Mircea Eliade." ${ }^{26}$

This being said, the Italian thinker's theory was not only shaped by Eliade but also influenced by another giant in the twentieth century study of religion, namely Claude Lévi-Strauss. While it is certainly correct that Lévi-Strauss took a decisive step away from the insider-phenomenological approach, de Martino understood that the crisis within the discipline of religious studies during his time was not only one of a split between seemingly incommensurable positions but also one of a lack of self-awareness. In fact, he believed that the two paradigmatic representatives of the insider and the outsider approaches had much more in common than they themselves thought.

First of all, they shared a thematic interest. Just like de Martino and Eliade, the French anthropologist dedicated much of his intellectual activity to the study of magic and shamanism. Born in the same year as de Martino and a year after Eliade, he shared important preoccupations that were cultivated by his Italian and Romanian colleagues. It was in 1949-in between the publications of de Martino's The World of Magic and Eliade's Shamanismthat Lévi-Strauss published two of his most influential articles on the topic, namely "The Sorcerer and His Magic" and "The Effectiveness of Symbols." ${ }^{27}$ In his analysis, the French anthropologist applied himself to interpret a song of healing that was uttered by a Cuna Indian shaman during an obstructed labor. Lévi-Strauss suggested that the shaman's séance of healing plays on mythical motifs of Indian culture and that this allows him to alleviate the pain of the woman. During the episode, the spiritual healer envisions that the soul of the laboring mother was stolen by Muu, the sacred power regulating the gestation of the fetus. What ensues is a journey upon which the shaman must embark in order to recover the captured soul. As he travels to the country of Muu and her daughters, these mythical locales become identified with the human body, specifically with physical attributes relevant to a woman in labor. The way of Muu becomes her vagina, whereas the abode of the mythical demon signifies the uterus of the pregnant woman. Throughout the song, the shaman retells

\footnotetext{
26 De Martino, 43-44.

27 Claude Lévi-Strauss, "L'efficacité Symbolique," Revue de L'histoire des Religions 135, no. 1 (1949): 5-27; Claude Lévi-Strauss, "Le sorcier et sa magie," Les Temps Modernes 41 (March 1949): 385-406. Both articles were republished in Structural Anthropology: Claude Lévi-Strauss, "The Sorcerer and His Magic," in Structural Anthropology (New York: Basic Books, 1963), 167-85; Claude Lévi-Strauss, "The Effectiveness of Symbols," in Structural Anthropology (New York: Basic Books, 1963), 186-205.
} 
his struggle against evil spirits and the culminating battle against Muu over his patient's soul. Finally, isomorphically linked through the healer's song, both the shamanic flight and the physical labor culminate in triumph: Just as the spirit releases the soul of the mother, the obstacles to the delivery of her baby are removed.

De Martino held the French anthropologist's interpretation of magic in high esteem, analyzing it repeatedly and extensively throughout a series of writings during the 195 os and $1960{ }^{28}{ }^{28} \mathrm{He}$ was so impressed with Lévi-Strauss' account of the Cuna healing song that he published a translated version of the latter article in his Magic and Civilization. ${ }^{29}$ De Martino also addressed at least one letter to his colleague, attaching a copy of one of his own books of the Southern Trilogy. ${ }^{30}$ The Italian historian of religion saw Lévi-Strauss as an ally because he shared his conviction that the "fundamental perspective to evaluate the efficacy of magical symbols is not naturalistic but historicalcultural." ${ }^{31}$ Lévi-Strauss' interpretation, in fact, was not naturalistic. The other way around, the anthropologue argued that the song's therapeutic efficacy rests in the isomorphic relationship between the symbolic realm of the text and the severe physical parturition difficulties. As de Martino himself noted, "the part of the magic enchantment (incantesimo) that narrates the shamanistic agon against Muu maintains itself constantly between mythical symbolism and physiological realism, with a continual passage from one to the other level." ${ }^{32}$ In other words, de Martino saw in Lévi-Strauss' account-marked by an oscillation between "the symbolic description of that which we could call the visceral landscape and the continual reference to the physiological reality of the uterine world in labor"33_ glimpses of his own endeavors during the 1950s. As I will show later, during those years, de Martino was one of the first

28 De Martino, "Mito, scienze religiose e civiltà moderna"; Ernesto De Martino, "L'approccio etnologico della fenomenologia paranormale," Giornale Italiano per la ricerca psichica 1, no. 2 (May 1963): 81-86; Ernesto De Martino, "La Funzione Della Magia Nel Mondo Primitivo," Vie Nuove, October 22, 1964; De Martino, La fine del mondo, 266-68, 403-7, $623-26$.

29 Claude Lévi-Strauss, "L'efficacia dei simboli magici," in Magia e civiltà, ed. Ernesto De Martino (Milano: Garzanti, 1962), 222-46.

30 I will discuss de Martino's Southern Trilogy in the following chapters. In a letter sent on October 2 1961, Lévi-Strauss thanks his colleague for sending him the "beautiful book," promises that he "will read it with considerable interest," and assures him that he will write a "report on it." Pietro Angelini, "Dall'epistolario di Ernesto de Martino," Quaderni del dipartimento di scienze sociali dell'Istituto universitario orientale III, no. 3-4 (1989): 211.

31 De Martino, Magia e civiltà, 220-21.

32 De Martino, "Mito, scienze religiose e civiltà moderna," 49.

33 De Martino, 49. 
to argue that the phenomenon of "Tarantism" (tarantismo) - involving spiderbitten women in the Italian South, exorcised by means of the ritual playing of the Tarantella - was not the result of a merely biological disease but rather a cultural phenomenon imbued with a rich symbolic horizon. Just as in the case of Lévi-Strauss' laboring woman, the Tarantate were not healed by means of physical intervention but rather through the efficacy of cultural practices.

De Martino brought his own predilection for how magic alters the conception of time in order to overcome difficult situations to his reading of Lévi-Strauss's piece on the Cuna healing ritual. Noting that the "magic performance of the shaman opens with a long and meticulous descriptionlike a film in slow-motion - of the antecedents of the present situation," de Martino proceeded to emphasize aspects that remind us of his own treatment of the efficacy of magic practices. More specifically, he recovered the expression "stepping backwards," which we already encountered in his discussion of Eliade, and applied it to the French anthropologist's theory of magic healing.

[The song] narrates the beginning of the crisis, the loss of consciousness of the midwife, her visit to the shaman, the shaman's departure to the hut of the parturient, and his arrival. In other words, his "cure" initiates with a step backwards that reclaims the events of retrospective interest starting from the inception of the crisis. With an incredible abundance of details it incisively describes - as if "recommencing from the beginning"-[...] the complete sequence of events. ${ }^{34}$

In "Myth, Religious Studies, and Modern Civilization," de Martino used strikingly similar terms to introduce Lévi-Strauss' study. Here too, he argued that what unites his own work with that of the French structuralist is the emphasis on "the step backward" (passo indietro), noting that it operates through a "ritual return of an initial mythic situation." ${ }^{35}$ He proceeds to note not only that the "structure of this magic enchantment demonstrates a complex symbolism," but also specified that "this symbolism is oriented in part towards the recovery of the initial situation, and in part towards the reliving of the conflicts and somatic processes of the labor in resolved terms."36

Of course, while it is not his dominant focus, such a "temporal" reading of Cuna shamanism is by no means absent in the French structuralist's interpretation. De Martino astutely supported his interpretation by citing Lévi-Strauss'

34 De Martino, "Lapproccio etnologico della fenomenologia paranormale," 82.

35 De Martino, "Mito, scienze religiose e civiltà moderna," 48.

36 De Martino, 49. 
own observation on the fact that "everything occurs as though the shaman were trying to induce the sick woman-whose contact with reality is no doubt impaired and whose sensitivity is exacerbated - to relive the initial situation through pain, in a very precise and intense way, and to become psychologically aware of its smallest details." ${ }^{37}$ Throughout his examination of the Cuna healing episode, de Martino integrated the positions of Lévi-Strauss with those of Eliade. Fundamentally, he set up Lévi-Strauss' account in between that which is "antecedent" (antecedente) and "initial" (iniziale), on the one hand, and that which "present" (presente), on the other. Not only that. He also reproduced the idea of a ritual repetition of the myth, which he inherited from Eliade, in order to bring movement into those two extremes on the temporal spectrum. Notions that de Martino used abundantly throughout his analysis of Lévi-Strauss' work- the "the step backwards" (passo indietro), "slow down" (rallentare), "recovery" (ripresa), "reliving" (rivivere), and "starting from the top" (ricominciare da capo) - serve to highlight the importance of a dehistoricized temporality even if that idea has a negligible relevance in the French anthropologist's study.

\section{2 \\ Historicizing the De-historifying Tendencies of the Modern Magicians in the Study of Religion}

De-historification-focusing on the trope of the "step backwards" - involved not only the establishment of a dialogue between two seemingly incommensurate perspectives within a split discipline, but also a historicization of the crisis itself. In other words, de Martino suggested that his fellow scholars of religion were trying to salvage their discipline's presence through de-historification just as the shaman did in primitive society. This attitude was particularly prevalent in his treatment of Eliade, whom de Martino accused of taking the religious practitioner's account at face value, so much so that the "pretense" to abolish history "ends up becoming the theory, even the theology of the anthropologist and of the historian of religion, who is thus himself being transformed into a mystic and an occultist in front of our eyes."38 The most articulate critique of this position is to be found in de Martino's collective review of three of Eliade's writings-besides the ever-present The Myth of the Eternal Return (1949), he also addressed Shamanism: Archaic Techniques of Ecstasy (1951),

37 Lévi-Strauss, "The Effectiveness of Symbols," 193.

38 De Martino, "Etnologia e cultura nazionale negli ultimi dieci anni," 329. For an almost identitical formulation, see also, De Martino, 337. 
and the Eranos Jahrbuch article entitled "Psychology and History of Religions: Concerning the Symbolism of the "Center" (1951). ${ }^{39}$ In his review, written in 1952, after recognizing his debt to Eliade's idea that religion consists of a "the ritual iteration of mythic archetypes," de Martino proceeded to express his reservations: "Where we can't follow the author-and here, we fear that he risks to confuse the true motive for the hermeneutic theme proposed by him-is in the anti-historic polemic, which, to say it candidly, seems to me to be set up on a radical misunderstanding of what historicism is in its most mature form."40

The Italian historian of religion contended that the flight from history, which Eliade observed in religion, was not only impacting his ahistorical approach, but also shaped his personal anti-historical philosophical orientation-so that "any distinction between science and object of science, between religious historiography and religious worldview is wiped out." ${ }^{\text {"1 }}$ In response, de Martino reasserted his conception of historicism as "a theory of human (not mythic) productivity of cultural values," according to which "even the religious pretension to save oneself from history, is part of history."42 In another writing from the mid-195os, de Martino expressed this commitment to a secularist and historicist reading of religion as follows:

On the contrary, even though religious de-historification is lived by the believer as refusal of the "human condition," what it brings about is not a real de-historification, [...] but rather the opening up of the operative powers of man, so that he matures in the shadow of the divine and the profane; and the secular discloses itself within the sacred. ${ }^{43}$

39 Mircea Eliade, "Psychologie et histoire des religions, à propos du symbolisme du 'Centre," in Eranos-Jahrbuch: Mensch und Ritus, ed. Olga Fröbe-Kapteyn, vol. 19 (Zürich: RheinVerlag, 1951), 247-82. Ernesto De Martino, "Recensione a M. Eliade, 'Le mythe de l'éternel retour, archétypes et répétition,' 'Psychologie et histoire des religions, à propos du symbolisme du "centre", 'Le chamanisme et les techniques archaïques de l'extase,"' Studi e materiali di storia delle religioni 23 (1952): 148-55.

40 De Martino, "Recensione a M. Eliade, 'Le mythe de l'éternel retour, archétypes et répétition,' 'Psychologie et histoire des religions, à propos du symbolisme du "centre", 'Le chamanisme et les techniques archaïques de l'extase," 149.

41 De Martino, $15^{2-53}$.

42 De Martino, 149-50.

43 Ernesto De Martino, "Fenomenologia religiosa e storicismo assoluto," in Storia e metastoria: i fondamenti di una teoria del sacro, ed. Marcello Massenzio (1954; repr., Lecce: Argo, 1995), 63 . 
De Martino's critique of the second de-historifying magician of the twentieth century, Lévi-Strauss, is subtler in nature. This is, at least partly, due to the fact that the French anthropologist was not primarily concerned with the question of time. While we saw that de Martino interpreted Lévi-Strauss' account of shamanic healing through a temporal horizon - the "step back"there is no doubt that the latter's structuralism was not amenable to such an approach precisely because of its neglect for history. As Dosse noted, in structuralism "war was declared against historicism, the historical context, the search for origins, diachrony, teleology and the argument was made in favor of permanent invariables, synchrony, and the hermetic text." ${ }^{\text {4 }}$ Inspired by the linguistics, Lévi-Strauss asserted the primacy of universal structures of the human mind over historical variations in different cultures. Already in The Elementary Structures of Kinship (1949), ${ }^{45}$ Lévi-Strauss distanced himself from historians and their genetic approach. According to the French scholar, the origin of the structures that the anthropologist studies is nowhere near as important as their function within the system.

De Martino, however, quickly realized that this apparent disregard for history is ultimately just as much a result of the crisis of modernity as Eliade's nostalgia of the illo tempore. Paradoxically, it is precisely this emphasis on a universal functioning rather than specific historical origins and developments that the structuralist instantiation of the outsider-explanatory approach comes to join the so-called "historians of religion" of the insider-phenomenological orientation. Let us recall Mircea Eliade's own conception of how the history of religions is to contemplate myth:

Becoming aware that every religious form has a history and that is built into a well-defined cultural complex does not complete the task of the historian of religions. In fact, he still has to understand and clarify the meaning, the intention, and the message of this religious form. [...] In other words, the historian of religions is required by his scientific discipline to deal with the timeless constants of religious experience and with the structures, irreducible to historicity, which derive therefrom. ${ }^{46}$

Like Lévi-Strauss, Eliade prioritized timeless structures over historical particulars. It is in this nostalgia for the archaic structures-what Eliade

\footnotetext{
44 Dosse, History of Structuralism. Vol. 1: The Rising Sign, 1945-1966, 386, 23.

45 Claude Lévi-Strauss, Les structures élémentaires de la parenté (Paris: Presses Universitaires de France, 1949).

46 Mircea Eliade, "Mythologie et histoire des religions," Diogène 9 (January 1955): 101-2.
} 
repeatedly called the "timeless constants of religious experience"47 - that de Martino rightly pinpointed a crucial communality between the Romanian historian of religion and Lévi-Strauss' structuralist endeavor. Both Eliade and Lévi-Strauss-despite their radically different positions on the insideroutsider, phenomenology-explanation, essentialization-naturalization spectrum - were ultimately more intent on finding structures rather than content, constants rather than transformations, mental invariants rather than cultural particulars. For both scholars, the study of religion was premised on the search for universals, with historical evidence being hardly more than the raw material upon which to build the structure of a universal category, whether this be kinship, myth, or the homo religiosus.

De Martino's intuitions have been confirmed by some contemporary researchers. Paul-François Tremlett, speaking of "a number of perhaps counterintuitive similarities between structuralism and the phenomenology of religion," rightly emphasizes their shared "strategic essentialism." ${ }^{48}$ In "Religious Symbolism and Historical Becoming," another one of the rare articles discussing this matter, the Italian anthropologist Sonia Giusti spoke about the parallels in their respective approaches to history as follows:

Lévi-Strauss' affirmation that it is not men who tell myths but rather myths who narrate men also counts for Eliade. In both cases, one tries to understand, through myths, the reasons for human behaviors on the bases of universal structures. The difference is that while for Lévi-Strauss the motifs for myths are to be found in the mental structures by means of which humans culturally perceive the world, for Eliade the motifs for myths are located in the metaphysical structures, which explode in symbols. ${ }^{49}$

The anthropologue was particularly passionate about myths as an expression of a culture's unconscious, arguing that his studies of myths were able to discover underlying and universal structures of cultures. Comparing the study of myths to the analysis of grammar, he believed that the meaning of mythical stories lies not in their content, but rather in their structure. Citing Carmen

47 For another example, see one of his letters to his teacher Pettazzoni: Mircea Eliade and Raffaele Pettazzoni, L'histoire Des Religions a-t-Elle Un Sens? Correspondance 1926-1959, ed. Natale Spineto, CERF (Paris: Le Cerf, 1994), 62.

48 Tremlett, Lévi-Strauss on Religion, 101.

49 Sonia Giusti, "Simbolismo religioso e divenire storico," in Confronto con Mircea Eliade: archetipi mistici e identità storica, ed. Luciano Arcella, Paola Pisi, and Roberto Scagno (Milano: Jaca Book, 1998), 419-20. 
Bernand, we could say that "the content disappears in favor of the structural

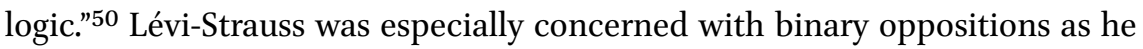
considered them to be the most dominant structural logic of both language and myths. In the words of another commentator, we could say that "dividing the world into mutually exclusive categories produces meaning: culture/ nature, man/ woman, black/white, good/bad, us/them."51 Besides Freudianism, it is well known that Lévi-Strauss developed his thinking about culture in close reliance upon linguistics, which he considered to be the most "scientific" of all the social sciences..$^{52}$ Of particular importance was the work of the Swiss linguist Ferdinand de Saussure (1857-1913). ${ }^{53}$ Saussure's Course in General Linguistics (1916), consisting of notes by his students on a series of lectures given at the University of Geneva, is famous for making linguistics into a system based on difference and relationships. ${ }^{54}$ According to Saussure's theory, the "signifier" (le significant, e.g. the sound image "cat") and the "signified" (le signifié, e.g. the concept or mental image of a cat) are not given naturally, but stand in an arbitrary relationship. ${ }^{55}$

Now, in Saussure's linguistics, this arbitrariness of language is counteracted by the emphasis on a fixed system of language (langue). ${ }^{56}$ AsTerence Hawkes has illustrated, Lévi-Strauss appropriated Saussure's system of linguistics to offer a universal science of culture. Thus, although he "stalks it through the particular varieties of its parole," the French anthropologist's priorities are not idiographic but rather nomothetic as he searches for "the langue of the whole culture, its system and its general laws." ${ }^{57}$ It has even been argued that "in his scheme the diversity of local nuance is lost in the unity of universal systematicity."58 Against the grain of the paradigms of cognitive, cultural, and historical

$50 \quad$ Carmen Bernand, "Anthropologie religieuse," in Théories de la religion: diversité des pratiques de recherche, changements des contextes socio-culturels, requêtes réflexives, ed. Pierre Gisel, Jean-Marc Tétaz, and Valérie Nicolet Anderson (Genève: Labor et Fides, 2002), 160. Storey, Cultural Theory and Popular Culture, 239.

52 Claude Lévi-Strauss, "L'analyse structurale en linguistique et en anthropologie," Word 1, no. 1 (April 1, 1945): 33-53.

53 Michael Lane, Structuralism: A Reader (London: Cape, 1970), 13-14; Dosse, History of Structuralism. Vol. 1: The Rising Sign, 1945-1966, xxii, 200.

54 Ferdinand de Saussure, Cours de linguistique générale (Lausanne: Payot, 1916), 144, 168-69.

55 Saussure called the arbitrariness of the link between signifier and signified "the first principle of linguistics." Saussure, 100, 182; Jonathan Culler, Saussure (London: Fontana Press, 1976), 19-29.

56 Saussure, Cours de linguistique générale, 182-83; Roy Harris, Reading Saussure: A Critical Commentary on the Cours de Linguistique Générale (La Salle: Open Court, 1987), 132, 219.

57 Terence Hawkes, Structuralism and Semiotics (London: Methuen, 1977), 39.

$5^{8}$ Paul Stoller, "Rationality," in Critical Terms for Religious Studies, ed. Mark C. Taylor (Chicago: University of Chicago Press, 1998), 246. 
relativism, Lévi-Strauss argued that there existed a hidden but universal pattern organizing all human mental and cultural life. Russell T. Mccutcheon, a declared advocate for the outsider-explanatory approach to religion, emphasizes that this tradition "models itself after the natural sciences in attempting to generate universal theories of human behavior from the analysis of specific cases." ${ }^{2} 9$ This approach is "based on certain generalized regularities in their observations, generalizations which they might label as laws," aiming at determining "the economic, political, psychological [...] causes" of religious behavior. ${ }^{60}$

In posthumously published notes, ${ }^{61}$ de Martino discussed Lévi-Strauss' "History and Anthropology" (1949), which would become the opening essay of Structural Anthropology. ${ }^{62}$ Here, he noted that his French colleague made a distinction between the science of history, which "organizes its data in relation to conscious expressions of social life," and anthropology, which "proceeds by examining its unconscious foundations." ${ }^{\text {"33 }}$ Lévi-Strauss himself wrote:

The issue can thus be reduced to the relationship between history and ethnology in the strict sense. We propose to show that the fundamental difference between the two disciplines is not one of subject, of goal, or of method. They share the same subject, which is social life; the same goal, which is a better understanding of man; and, in fact, the same method, in which only the proportion of research techniques varies. They differ, principally, in their choice of complementary perspectives: History organizes its data in relation to conscious expressions of social life, while anthropology proceeds by examining its unconscious foundations. ${ }^{64}$

As one commentator aptly put it, it is "the radicalization of these notions like system and model, sometimes mathematizable (mathématisable) like structures of kinship," which forms the basis for his firm belief in the "incontestable

59 Russell T. McCutcheon, ed., The Insider/Outsider Problem in the Study of Religion: A Reader (London: Cassell, 1999), 128.

6o McCutcheon, 5 .

61 De Martino, La fine del mondo, 403-5.

62 Claude Lévi-Strauss, "Histoire et ethnologie," Revue de Métaphysique et de Morale 54, no. 3/4 (1949): 363-91; Claude Lévi-Strauss, "Introduction: History and Anthropology," in Structural Anthropology (New York: Basic Books, 1963), 1-30.

63 Claude Lévi-Strauss, Structural Anthropology (New York: Basic Books, 1963), 18. See also, Claude Lévi-Strauss, "Histoire et ethnologie," Revue de Métaphysique et de Morale 54, no. 3/4 (1949): 363-91.

64 Lévi-Strauss, "Introduction: History and Anthropology," 18. 
superiority of anthropology over history." ${ }^{\prime 5}$ Later in life, de Martino increasingly started to regard the work of the French structuralist as a problematic endeavor. Telling the story of how Lévi-Strauss argued that the anthropologist should assume "the point of view of God [...] to understand humans as if they were completely outside of the game (fuorigioco) [...] as if he were an observer of an unknown planet and as if he had an absolutely objective and complete perspective, $[. .$.$] as if they were ants," { }^{\prime 66}$ de Martino continued:

It seems to me that this scientific ideal of considering humans like ants transforms itself into the prophetic message that humanity reduces itself inevitably into a sort of anthill: that is, the message that humanity inevitably advances towards an apocalypse without eschaton, towards the total ruin of what is human. This then is not even any longer a prophetic message but a cold scientific prediction, which already dictates that we should adapt to the event just as it is necessary to adjust oneself in the autumn for the following and inevitable winter. ${ }^{67}$

De Martino, in response, remarked that such "distinctions do not hold up because historiography has always been engaged, at least in its more mature age, in reconstructing the unconscious motivations and the unintentional results of the human acting in society." ${ }^{\prime 8}$ He described Lévi-Strauss' division as "artificial and incongruous," and argued instead that "all that there is, is the one historical science." ${ }^{69}$ According to de Martino, this type of historian is not primarily interested in "reproducing the manner in which the consciousness of the historical agents comprehends its own acting." Rather, "after having ascertained this consciousness, he moves $[. .$.$] to reconstruct the true meaning of$ an individual initiative, an institution, an epoch, a civilization, and, in general, any 'event." De Martino emphasized that this move is a move "beyond"-both in the "sense of its motivation and its results." It is a maneuver, he specified "beyond the consciousness, which the contemporaries that were engaged in it would have had" of their own historical action.

Invoking Karl Marx's dictum that "men make their own history, but they do not know that they are making it" (gli uomini fanno la loro propria storia, ma non sanno che (a fanno), de Martino further noted that Lévi-Strauss used "this

65 Richard Marin, "La Nouvelle Histoire et Lévi Strauss," Caravelle. Cahiers Du Monde Hispanique et Luso-Brésilien, 2011, 165.

66 De Martino, La fine del mondo, 689.

67 De Martino, 689-9o.

68 De Martino, 404.

69 De Martino, 405-6. 
famous formula" in the sense that the "first term justifies history, the second anthropology." ${ }^{\prime 70}$ Thus, de Martino ultimately criticized his French colleague for the same reasons that he rejected Eliade's conception of science. By relegating the actual historical circumstances outside of the purview of their intellectual endeavors, they not only rejected the study of history in societies where magic is practiced but also failed to address their own anti-historical bias. In other words, de Martino used his theory of de-historification to historicize his contemporaries' tendency to flee from history. De Martino, by contrast, gave Marx's notion a different spin, as he used it as an argument for an integrated and unified historical science that studies the historical import of magic both in its explicit and implicit dimensions:

$[\ldots]$ it is also to be noted that $[\ldots]$ the writer of this formula - and in reality the entire orientation of Western civilization-is a man who "knows" that human history is made by men. This is why the formula of Marx justifies the use of a unitary historicist criterion in the interpretation of all human facts. This criterion is the recognition that any historiographical research starts from the analysis of conscious human facts to move towards the problem of the "unconscious" results of human actions [that lie] beyond the motivations and objectives, which come to the awareness (coscienza) of the actors: Historically "true" is the entire process, which leads from the unconscious motivations, via a certain necessary limitation of consciousness, to trace back to certain results which are found beyond this limitation. ${ }^{71}$

De Martino's theory of religion as de-historification would remain central to his work until the end of his life. In posthumously published notes from his final years of research, we find passages in which he both acknowledges the mechanism of religious life as Eliade saw it and decisively argued for its profoundly worldly and civilizational function.

If one does not accept [the autonomy of humanity] then there is nothing left to do but to negate the reality of this condition, to conceal it and mask it in the grand protective themes of religious life, of myth and ritual, of theology and metaphysics, of magic and mysticism. There is nothing left to be done than to reduce the rhythms of daily labor to a world of

\footnotetext{
70 De Martino, 404. For the passage, on which de Martino comments, see Lévi-Strauss, "Introduction: History and Anthropology," 23.

71 De Martino, La fine del mondo, 405.
} 
signs and symbols and to carry out the task of establishing - here and now-a new order in the shadow of an order that is already established in illo tempore. In that case, the doing (ilfare) will be masked in repeating and in imitating, the being awake will be included in dreaming, and one will be in history as if not being part of it because one is already outside of it. However, in the meantime through this pia fraus, one will work and create, and the building of civilization will be constructed. ${ }^{72}$

Amongst these final notes, we also come across reflections on some other pieces of writing of the French anthropologist that sport more sensibility to historical issues. Judging by a section entitled "The Concept of De-historification in Claude Lévi-Strauss," it appears that the Italian thinker intuited that the anthropologue's work was by no means devoid of thinking about the importance of history. On the contrary, de Martino cited a passage from The Savage Mind (1962), in which we read:

I have suggested elsewhere that the clumsy distinction between "peoples without history" and others could with advantage be replaced by a distinction between what for convenience I called 'cold' and 'hot' societies: the former seeking, by the institutions they give themselves, to annul the possible effects of historical factors on their equilibrium and continuity in a quasi-automatic fashion; the latter resolutely internalizing the historical process and making it the moving power of their development. ${ }^{73}$

Had de Martino lived another twenty years, his intuitions would have been confirmed. In fact, in later years, Lévi-Strauss took on a position that was strikingly similar to that of de Martino. In a paper presented at the Marc Bloch Conference in 1983, the French structuralist relativized his distinction between "hot" and "cold" civilizations, arguing that he "did not intend to define real categories but only a heuristic goal." In the same paper, which was published as "History and Anthropology" - taking the same name as his article written over three decades earlier-he further relativized his previous stance.

All societies are historical in the same way, but some admit it frankly while others revolt against it and prefer to ignore it. Thus, if one can rightfully classify societies on an ideal scale — not according to their degree of

72 De Martino, 356.

73 Claude Lévi-Strauss, The Savage Mind (Chicago: University of Chicago Press, 1966), 233-34. 
historicity, which is similar for all of them, but to the manner in which they feel it - it is important to locate and analyze borderline cases: under which conditions and in which form do collective thinking and individuals open themselves to history? When and how, do they no longer look at it as disorder and threat but instead see in it a tool for acting upon and transforming the present? ${ }^{74}$

Another example of this growing awareness of the historical reality in socalled "cold" societies comes from an interview with Didier Eribon from 1988. If he earlier described them as outside of history, he now notes that "they imagine themselves as primitives because their ideal is to stay in a state when the gods created them at the origin of time. Of course, they create themselves the illusion and don't escape history any more than all others." ${ }^{75}$ While de Martino would have wholeheartedly agreed with such statements-likely noting that the societies in question are the ones that have perfected the logic of producing history through de-historification - he nonetheless went further than the French anthropologist. In fact, the Italian thinker openly critiqued the contemporary scientists' tendency to de-historify time. In his discussion of Lévi-Strauss and Marx, for instance, de Martino demonstrated a dialectical approach, which moves decisively beyond any type of black and white, or hot and cold thinking. Instead, he insisted that Marx's formulation needed to be relativized as the two extremes are ultimately not capable of existing on their own. On the one hand, "if men really did absolutely not know [that they make history], they could never conquer this knowledge." On the other hand, "if this knowledge could one day be fully conquered and making history coincided precisely with the operative consciousness that one has of it, on this day history would also end. [In that case], historiography would kill history."76

\section{The Magic Christ of Science: Heroic Historicism and the Active Provocation of Crisis in Pursuit of Critical Thinking}

In introducing de-historification, I noted that it is intended to help individuals and societies overcome critical moments of existence by transporting historical reality into a space outside of time. It operates by temporarily concealing the destructive potential of the crisis by transposing the present events into a

74 Claude Lévi-Strauss, "Histoire et ethnologie," Annales 38, no. 6 (1983): 1218.

75 Claude Lévi-Strauss, De près et de loin, ed. Didier Eribon (Paris: O. Jacob, 1988), 176.

$7_{6}$ De Martino, La fine del mondo, 405 . 
metahistorical realm where the incidents are actively mastered and brought under control. In de-historification, the crisis has always already been resolved at the beginning of time. Now, basing his study on the countless examples he drew from ethnographies of primitive societies, de Martino argued that dehistorification may also work by actively simulating or provoking a crisis. The shaman, according to this understanding, is a heroic figure who protects the presence of others through his courageous engagement in magical practices. De Martino went even as far as calling the shaman a "veritable magic Christ, mediator for the entire community of being-in-the-world as redemption from the risk of not-being-there." ${ }^{77}$ In other words, what sets the shaman apart from other members of the community is that he actively seeks out the crisis. The shaman is the key protagonist in the world of magic and the technique of dehistorification precisely because he actively provokes the instability of the self through trance-like states.

While the members of the community can lose their united presence without restitution, in such a way that their fragile being-there is an unstable psychic cosmos that risks to precipitate into chaos at any moment, the shaman is the hero that knew how to bring himself to the threshold of chaos and that has been able to make a pact with it. Indeed, it is because the shaman has become the unconditional master of his own frailty, that he has also acquired the capacity to overcome the limits of his own being-there and to make himself into the clairvoyant and organizing center of the weakness of others. ${ }^{78}$

Likewise, since de Martino's discussion of shamanic magic as de-historification always fertilized his understanding of science during the years before and after WWII, it is not surprising that he applied the move from crisis to recovery to his analysis of religious studies. Becoming a magic Christ himself, a "mediator for the entire community (of scientists)," he used de-historification to lead his field from the state of a split discipline that is driven blindly by its antimagical polemic to a critical discourse on magic. De Martino described this type of approach "heroic historicism" (storicismo eroico), ${ }^{79}$ and argued that his philosophy of science is dedicated to "the boundless task of spiritual resolution of reality, which, thanks to effective thinking, melts time after time the intellectualist concretion that seems to put a limit to immanence. Time and

77 De Martino, Il mondo magico, 98.

78 De Martino, 94-95.

79 De Martino, 3. 
time, it leads the inertia of the fact (fatto) back to human making (fare) and molding (plasmare)." ${ }^{\prime 80}$ Like the shaman's practice of redemption of the presence, however, this movement is never linear, but rather a dialectical process that uses crisis as the motor for recovery. De Martino's own growth as a thinker in religious studies operated by means of a stitching movement in between two tissues that only exist because of the rupture within the discipline itself.

Let us look at this heroic process of unifying a ruptured science in more detail. De Martino usually opened up his articles on de-historification by praising the importance of the insider-phenomenological approach for excelling at "the description of that which appears to the consciousness of the believer"-such as "the encounter with the numinous, the being seized by the radically other, the reabsorption of the here and now in the ritual repetition of an inaugural metahistorical event, [and] the permanent nexus between mythic figuration and ceremonial act." 81 However, in all of his writings, de Martino was equally quick at curtailing his enthusiasm with the caveat that this methodological orientation limits its analysis to the position of the believer: "That which is the starting point for the man engaged in religion," so he wrote, "constitutes [...] only a stage or a moment of the true hierogenetic process to be reconstructed." By invoking the slogan "Mitsingen ist verboten," which is "written on a sign in the concert halls of Germany," de Martino explains that "for the historian of religion in any capacity, it is equally forbidden to compete with the believers in the immediate testimony regarding the presence of the numinous." ${ }^{2}$ Specifically, de Martino distanced himself decisively from Eliade's abolition of history. Just as the two authors disagreed about the "reality" of magic, so they differ in their conception of the "reality" of de-historification. In his $195^{2}$ review to The Myth of the Eternal Return, de Martino succinctly described the difference in their respective positions as follows:

Eliade affirms that man opposes history even when he attempts to make it—even when he pretends to be nothing else than history_-but the truth is that man is in history even when he pretends to escape it. As a consequence, from this perspective, the great cultural theme of the iteration

\footnotetext{
8o De Martino, 4.

81 Ernesto De Martino, "Mito e religione," in Profezie e realtà del nostro secolo: testi e documenti per la storia di domani., by Franco Fortini (Bari: Laterza, 1965), 534.

82 De Martino, "Storicismo e irrazionalismo nella storia delle religioni," 77.
} 
of mythic archetypes appears like a paradoxically productive pretense, which—despite its [contrary] intention—is new history. ${ }^{83}$

Just like Guilford Dudley — who defined him as an "anti-historian of religion"84 — Vittorio Lanternari-who described him as dominated by a "visceral antihistoricism inspired by a vein tending towards mysticism"85_or Gavin Flood - who accused him of "implicit theological and ahistorical understanding of religion"86 — de Martino realized that Eliade's inability to distance himself from the believer's point of view seriously hampered his hermeneutic approach to religion. In what might be the most concise summary of the controversy between the two, Nicola Gasbarro notes how de Martino differs from Eliade because he insists on a distinction between the mechanism of dehistorification active in religious practice, on the one hand, and the scholars historicizing activity guiding his interpretation, on the other.

For Eliade, the mythic-ritual nexus is dehistoricizing: the situation of crisis is traced back to a mythic model that has already resolved the unresolvable, and the ritual does nothing more than to sacrally repeat this paradigmatic miracle. De Martino is concerned with a technical dehistorification that leads to redemption, to the entry into the specific cultural history, transforming the given situation into value. The mechanism is dehistoricizing, but the effect and the function are historical. ${ }^{87}$

De Martino's confrontation with Eliadean ideas about religion and history remained stable throughout his life. For instance, in the notes for his posthumously published book on the apocalypse, de Martino offered elaborate commentaries on several of his colleague's books. In a section dedicated to Myths, Dreams and Mysteries (1957), he observed that "historiography has the task to convert that which men believe to do, into that which men are really doing in order to legitimize either their beliefs or the reality that manifests

83 De Martino, "Recensione a M. Eliade, 'Le mythe de l'éternel retour, archétypes et répétition,' 'Psychologie et histoire des religions, à propos du symbolisme du "centre”,' 'Le chamanisme et les techniques archaïques de l'extase," 15 o.

84 Guilford Dudley, "Mircea Eliade as the 'Anti-Historian' of Religions," Journal of the American Academy of Religion 44, no. 2 (1976): 345-59.

85 Vittorio Lanternari, La mia alleanza con Ernesto de Martino e altri saggi post-demartiniani (Napoli: Liguori, 1997), 24.

86 Gavin Flood, Beyond Phenomenology: Rethinking the Study of Religion (London: Continuum, 1999), $5^{-6 .}$

87 Nicola Gasbarro, "Ernesto de Martino: microstoria di un 'nostro," Studi e materiali di storia delle religioni 51, no. 9 (1985): 219. 
itself because of them." ${ }^{88}$ De Martino, deeply grounded within the discipline of religious studies, was cognizant that the field gave rise to scholarly approaches that were precisely trying to distinguish between that what people believe to be doing and that what they are truly doing. One of these thinkers, of course, was Claude Lévi-Strauss. In his study of the shamanic healing practice, for example, the French anthropologist famously interpreted the shaman's activity that he encountered in the region of northwest Colombia and southern Panama as a form of psychoanalysis. In his study, Lévi-Strauss made frequent reference to the work of Sigmund Freud, speaking of psychoanalysis as "the modern version of shamanistic technique." 89

In both cases, the purpose is to bring to a conscious level conflicts and resistances which have remained unconscious, owing either to their repression by other psychological forces or-in case of childbirth-to their own specific nature, which is not psychic but organic or even simply mechanical. In both cases also, the conflicts and resistances are resolved, not because of the knowledge, real or alleged, which the sick woman progressively acquires of them, but because this knowledge makes possible a specific experience, in the course of which conflicts materialize in an order and on a level permitting their free development and leading to their resolution. ${ }^{90}$

Lévi-Strauss not only compared the traditional healer to a primitive psychoanalyst, but also made the claim that the mechanism of healing could operate in the same way as abreaction in Freudian analysis. According to this model of healing, the reaction of the treatment takes on both a mental and a physical dimension, even if it is elicited exclusively through psychological influence. Commenting on a series of "characteristics" that can be found in "the shamanic cure," the French anthropologist noted that "we know that its precondition is the unprovoked intervention of the analyst, who appears in the conflicts of the patient through a double transference mechanism, as a flesh-and-blood protagonist and in relation to whom the patient can restore and clarify an initial situation which has remained unexpressed or unformulated. All these characteristics can be found in the shamanistic cure."91 The Belgium-born theorist took inspiration from the Freudian theory of the

88 De Martino, La fine del mondo, 272-73. Eliade, Mythes, rêves et mystères.

89 Lévi-Strauss, "The Effectiveness of Symbols," 204.

$90 \quad$ Lévi-Strauss, 198.

91 Lévi-Strauss, 198. 
unconscious as he sought to discover the "unconscious foundations" of society. ${ }^{92}$ As anthropologist, Lévi-Strauss believed that his task was "to grasp, beyond the conscious and always shifting images which men hold, to the complete range of unconscious possibilities." 93

By acknowledging a deeper layer hidden behind the conscious awareness of humans, he recognized that the perspective of the religious practitioners needs to be critically investigated as they likely lack awareness of the true causes, reasons, and mechanisms of their beliefs. In The Raw and the Cooked (1964), Lévi-Strauss argued that he is not primarily preoccupied with how "men think in myths, but how myths operate in men's minds without their being aware of the fact." ${ }^{4}$ As André Green asserts, the French anthropologist contended not only that the "role of consciousness is to lie to itself," but also that the "unconscious structure plays the role of an indicator of the true message of the human spirit." 95

De Martino was attracted to the outsider-explanatory approach because it moves beyond pure phenomenology and description of myth and ritual in order "to explain why people employ either of these devices in their daily lives in the first place. ${ }^{16}$ Like the naturalistic current, de Martino was trying to move beyond the perception of the believer. However, unlike the type of approach propagated by thinkers like Donald Wiebe, he did not simply "presume that when religious people claim to have had supernatural experiences that defy rational explanation, they are mistaken in some way."97 On the contrary, while he accused Eliade of failing to critically question the pretenses of religious people, he criticized the proponents of the outsider-explanatory approach for disregarding the intentions of the believers.

Historiography, as science of the critique of human cultural actions (operosità culturale umana), is the measuring of the pretenses of human acting. It is the passage from that which man believes to be doing to that which he is really doing. Thus, it is the analysis of the unconscious motivations and of the unconscious results of a certain type of operating. But what man believes to be doing is not accidental in regards to that which

\footnotetext{
92 Lévi-Strauss, Structural Anthropology, 18.

93 Lévi-Strauss, 23.

94 Claude Lévi-Strauss, The Raw and the Cooked: Introduction to the Science of Mythology (New York: Harper \& Row, 1969), 12.

95 André Green, "Le rejet de la psychanalyse par C. Lévi-Strauss," Revue française de psychosomatique, no. 38 (December 13, 2010): 145 .

96 McCutcheon, Manufacturing Religion, 107.

97 McCutcheon, The Insider/Outsider Problem in the Study of Religion, 127.
} 
he really does. Limiting oneself to the reduction of all human pretenses to their effective reality is bad historiography because in this way the other important moment of the historical research stays in obscurity, namely the reconstruction of the historical necessity of the world of pretenses. [...] The sacred mythical-ritual symbolism includes, for example, a series of pretenses: But if one were to believe that one has completed one's own historical task by limiting oneself to reduce this symbolism to "that which men really do," then a whole series of problems of fundamental historical importance would fall away: The genesis, the structure, and the function of the mythical-ritual symbolism and its diverse ways of connecting itself to the totality of cultural life..$^{98}$

In this chapter, I showed that while de Martino's de-historification was a theory of magic that addressed the perplexing thoughts and practices he found in "primitive" societies, its ultimate aim hit much closer to home. Developing his thinking through a dialogue with Mircea Eliade and Claude Lévi-Strauss, he identified "magic" as a category of crisis that perfectly embodied modernity and produced a decisive split in the discipline of religious studies in the twentieth century. Evolving his approach beyond that of his more famous colleagues, he expanded the scope of de-historification to use it as a tool for critical thinking that actively engages the crisis through dialectics and historicization. De Martino regarded his own age as an age of magic. An age that is best imagined as the drama of the loss and redemption of the presence. On the one hand, the presence - that is the person, the individual, the being-inthe-world - is no longer guaranteed and under constant threat of being lost. On the other hand, we witness the emergence of extraordinary figures, who are capable of navigating these moments of crisis and to help their community overcome them. If de Martino called the shaman of the "primitive" age a "magic Christ," then he himself was a modern day shaman, a "hero of the presence." 99 Just as Sergio Berardini has rightly pointed out that "in the shaman, it is possible to see the 'first' weltgeschichtliche Individuum through which the spirit 'has become man,", 100 de Martino's critical theory of de-historification is an attempt to re-found the self as a historical actor in light of the crisis of modernity. De Martino's dialectical thinking reproduced the shamanic process of de-historification. Just as the shamanic crisis is a feigned one, de Martino at

98 De Martino, La fine del mondo, 46o.

99 De Martino, Il mondo magico, 122.

100 Sergio Fabio Berardini, Ethos, presenza, storia: la ricerca filosofica di Ernesto de Martino (Trento: Università degli studi di Trento, Dipartimento di lettere e filosofia, 2013), 132. 
first engaged with Eliade and Lévi-Strauss in a way that inevitably reproduced the crisis within the modern discipline of religions studies. In both cases, the dissolution of the self, the crisis of the presence-which is usually feared as an expression of utter abdication of identity — is voluntarily pursued and sought out. In a central passage of The World of Magic, we read:

[...] sometimes in the world of magic, the dissolution of being, the risk of the presence, seems to acquire the significance of a dominant ending that is voluntarily pursued. Solitude, darkness, fasting, very rigorous trials, orgiastic dance, concentration, monotonous chant, rolling of drums, incubations, fumigations, narcotics: Couldn't it be that these techniques appear for the stimulation of the trance and the deliberately sought-out collapse of the horizon? In that case, we would have to demonstrate that the presence of these techniques does not only contradict, but even confirm the theme of the threatened being-there that redeems itself. ${ }^{101}$

This unhinging and reassembling, this putting into crisis and subsequent redeeming, was nothing else than an expression of the heroic historicism that de Martino advocated as a response to the lazy historicism of mainstream Italian thinking during his time. As Pietro Angelini noted, "a 'heroic' historicism cannot and should not back down. The heroism, on the part of de Martino, is located precisely in this resolution to not write a history of magic. Because it is a history that is yet to be founded, and in order to do that it is required to descend on one's own into that dark crevasse out of which Western man has immerged, wounded but victorious." ${ }^{102}$ Due to his dialectical move from crisis to critique, complementing the insider-phenomenological insight into the functioning of religion with the outsider-explanatory thrust of analysis, de Martino would generally be harsher in his critique of Eliade than of Lévi-Strauss. However, as his dialectical method of thinking critically about religion would not come to rest in either one of the two extremes, we will soon see that de Martino not only expressed significant sympathy for the selfreflexive trends in Lévi-Strauss' Tristes Tropique, but also voiced increasingly harsh criticisms later in his life.

101 De Martino, Il mondo magico, 85-86.

102 Angelini, Ernesto de Martino, 31. 